\title{
ARANG ECENG GONDOK (Eichornia crassipes) SEBAGAI ADSORBEN FENOL PADA LIMBAH PLTU PALU
}

\author{
Charcoal of Hyacinth (Eichornia crassipes) as an Adsorbent of Phenol in Palu \\ PLTU Waste
}

\author{
* Mora Delfita Tudjuka, Daud K. Walanda, dan Baharuddin Hamzah \\ Pendidikan Kimia/FKIP - Universitas Tadulako, Palu - Indonesia 94118 \\ Recieved 13 March 2017, Revised 14 April 2017, Accepted 12 May 2017
}

\begin{abstract}
This study aims to determine the optimum capacity and weight of water hyacinth aroma to the adsorption capacity of phenol in Palu PLTU waste. The steps taken in this research are sampling of PLTU waste, making of adsorbent, determination of phenol concentration in PLTU waste and determination of phenol concentration at equilibrium using Spektrodirect spectrophotometer. The adsorption capacity of water hyacinth at optimum condition of phenol was determined by weight variations of 10, 20, 30, 40 and $50 \mathrm{mg}$. The resulting result after adsorption process for adsorption weight at the weight of charcoal $10 \mathrm{mg}=82.78 \%, 20 \mathrm{mg}=89.13 \%, 30 \mathrm{mg}=85.49 \%, 40 \mathrm{mg}=79.72 \%$ and $50 \mathrm{mg}=74$, $42 \%$. The optimum weight of charcoal in phenol absorb is $20 \mathrm{mg}$ with\% phenol which is absorbed $89,13 \%$. Capacity of adsorbent hailing of water hyacinth scent at optimum condition of $3.03 \mathrm{mg}$ phenollg of adsorbent.
\end{abstract}

Keywords: Adsorbent, charcoal, water hyacinth, phenol, adsorption, Spektrodirect spectrophotometer

\section{Pendahuluan}

Perkembangan industri yang sangat pesat beberapa dekade belakangan ini memberikan kontribusi yang sangat penting bagi peradaban manusia. Perkembangan tersebut memberikan banyak kemudahan dan keuntungan bagi kehidupan manusia. Walaupun memberikan keuntungan yang cukup besar, tetapi dilain pihak perkembangan industri yang sangat pesat ini memberikan sisi negatif yang terkadang tidak disadari oleh manusia. Hasil samping atau buangan dari industri yang dihasilkan dapat menimbulkan permasalahan bagi kesehatan manusia dan lingkungan (Murdika, 2009).

Pusat Listrik Tenaga Uap (PLTU) berbahan bakar batubara mempunyai reputasi baik karena mampu memproduksi listrik dengan biaya paling murah dibandingkan sistem pembangkit listrik lainnya. Biaya operasi PLTU batubara kurang lebih 30\% lebih rendah dibandingkan sistem pembangkit listrik yang lain. Namun sisi lain, PLTU batubara juga

Program Studi Pendidikan Kimia, Fakultas Keguruan dan Ilmu Pendidikan, Universitas Tadulako

mempunyai reputasi buruk karena merupakan sumber pencemar utama terhadap atmosfer kita, senyawa-senyawa seperti fenol, SOx dan NOx yang berbentuk gas dengan bebasnya naik melewati cerobong dan terlepas ke udara bebas. Kedua gas tersebut dapat bereaksi dengan uap air yang ada di udara sehingga membentuk $\mathrm{H}_{2} \mathrm{SO}_{4}$ (asam sulfat) dan $\mathrm{HNO}_{3}$ (asam nitrat). Keduanya dapat jatuh bersama-sama air hujan sehingga mengakibatkan terjadinya hujan asam Berbagai kerusakan lingkungan serta gangguan terhadap kesehatan dapat muncul karena terjadinya hujan asam tersebut (Dewilda, dkk., 2012).

Senyawa fenol merupakan polutan yang sering ditemukan diperairan laut. Fenol merupakan polutan aromatik, yang hadir dalam air limbah dari berbagai industri termasuk penyulingan minyak, petrokimia, batubara kokas dan batubara gasifikasi (Gerrard, dkk., 2006).

Konsentrasi senyawa fenol di perairan di atas $2 \mathrm{mg} / \mathrm{L}$ akan bersifat racun bagi ikan dan bila konsentrasinya antara 10 dan $100 \mathrm{mg} / \mathrm{L}$ dapat menyebabkan kematian lingkungan aquatik dalam waktu 96 jam. Konsentrasi standar maksimal yang ditetapkan oleh Depkes. 
RI untuk fenol adalah $0,001 \mathrm{mg} / \mathrm{l}$ sebagai konsentrasi maksimal yang dianjurkan dan $0,002 \mathrm{mg} / \mathrm{l}$ untuk konsentrasi maksimal yang diperbolehkan (Murdika, 2009).

Beberapa metode yang dapat digunakan untuk menurunkan konsentrasi fenol dalam limbah cair diantaranya adalah adsorpsi, pengendapan, penukar ion dengan menggunakan resin, filtrasi, dan dengan cara penyerapan bahan pencemar oleh adsorben baik berupa resin sintetik maupun karbon aktif. Diantara metode-metode tersebut, adsorpsi merupakan metode yang paling umum dipakai karena memiliki konsep yang lebih sederhana dan dapat diregenerasi serta ekonomis. Adsorpsi telah terbukti merupakan metode yang cukup efektif untuk mengolah limbah cair. Proses adsorpsi secara umum diartikan sebagai suatu proses dimana suatu partikel pada larutan melekat pada permukaan material adsorpsi (adsorben). Dimana adsorben merupakan zat pengadsorpsi. Proses adsorpsi dapat digambarkan sebagai proses dimana molekul meninggalkan larutan dan menempel pada permukaan zat adsorben (Reri, dkk., 2012).

Teknik adsorpsi terhadap fenol telah banyak dilakukan dengan menggunakan berbagai macam adsorben, seperti uji kemampuan karbon aktif dari limbah kayu dalam sampah kota untuk penyisihan fenol (Juliandini \& Trihadiningrum, 2008), penyisihan fenol dengan kombinasi proses adsorpsi dan fotokatalisis menggunakan karbon aktif dan $\mathrm{TiO}_{2}$ (Slamet, dkk., 2006), penyisihan fenol pada limbah industri dari PT XYZ dengan eceng gondok (eichhornia crassipes) (Hamamah \& Trihadiningrum, 2008), adsorpsi fenol oleh arang aktif dari tempurung biji jarak pagar (Jatropha curcas L.) (Wirawan, 2012), pembuatan karbon aktif dari arang tempurung kelapa dengan aktivator $\mathrm{ZnCl}_{2}$ dan $\mathrm{Na}_{2} \mathrm{CO}_{3}$ sebagai adsorben untuk mengurangi kadar fenol dalam air limbah (Pambayun, dkk., 2013), dan memanfaatkan adsorben zeolit alam untuk mengadsorpsi fenol dengan melakukan variasi suhu dan diperoleh penurunan fenol sebesar 23,3 mg/g pada suhu $55^{\circ} \mathrm{C}$ (Yousef, dkk., 2011).

Enceng gondok merupakan salah satu tumbuhan yang dapat melakukan adsorpsi. Kemampuan Eceng gondok untuk menyerap disebabkan eceng gondok mempunyai akar yang bercabang-cabang halus yang berfungsi sebagai alat untuk menyerap senyawa kimia, sehingga toksisitas senyawa kimia yang terlarut semakin berkurang.

Eceng gondok dapat juga dijadikan sebagai adsorben untuk logam berat, diantaranya $\mathrm{Pb}^{2+}$ (Faisal, 2015), Ni(II) dan $\mathrm{Cu}(\mathrm{II})$ (Shofiyani \& Gusrizal, 2006), Merkuri(II) (Krystyanti, 2008). Selain mengadsorpsi logam-logam berat, arang eceng gondok dapat juga menyerap amoniak (Zaman \& Sutrisno, 2006) dan digunakan untuk menurunkan kekeruhan, COD, BOD pada Air (Valentina, dkk., 2013).

Kandungan selulosa dalam eceng gondok kering sekitar 26\% yang dapat di konversi menjadi glukosa (Podolar, dkk., 1991). Menurut Valentina, dkk. (2013), telah diketahui bahwa eceng gondok mengandung protein sebanyak $17,1 \%$ dan lemak 3,6\% dan mengandung selulosa yang mencapai $18,2 \%$. Serat eceng gondok sebagian besar tersusun dari selulosa. Selulosa apabila dipanaskan pada suhu tinggi akan meninggalkan karbon sebagai hasil akhir yang terikat membentuk struktur segi enam dengan atom-atom karbon yang terletak pada setiap sudutnya dan memiliki pori-pori yang besar, sehingga dapat dijadikan sebagai adsorben untuk menyerap senyawa kimia dalam limbah diperairan. (Podolar, dkk., 1991)

Penelitian ini bertujuan untuk menentukan berat optimum dan kapasitas adsorpsi arang eceng gondok terhadap fenol dalam limbah PLTU.

\section{Metode \\ Alat dan Bahan}

Alat yang digunakan pada penelitian ini yaitu pipet tetes, cawan porselin, gelas kimia, gelas ukur, oven (MMM Medcenter Venticell), ayakan 70 mesh, neraca ohaus, shaker, labu ukur, lumpang dan alu, Tanur (1400 Furnance, BL Barnstead Thermolyne), Erlenmeyer, batang pengaduk, kertas aluminium foil, pipet ukur $25 \mathrm{~mL}$, botol semprot dan spektrofotometer spektro-direct (Lovibond Spectro2).

Bahan yang digunakan pada penelitian ini yaitu tanaman eceng gondok, aquades, tablet fenol (pro analis), sampel limbah PLTU dan Kertas saring Whatman $41 .$.

\section{Cara Kerja}

Pengambilan sampel limbah PLTU

Botol aqua yang telah dibungkus lakban hitam dimasukkan ke dalam air limbah keluar kondensor, kemudian membuka tutup botol di dalam air agar udara tidak ikut masuk ke dalam 
botol. Setelah botol terisi penuh, maka botol tersebut ditutup kembali di dalam air.

\section{Pembuatan arang eceng gondok}

Tanaman eceng gondok dibersihkan dari sisa-sisa kotoran kemudian daun, batang dan akar dipisahkan dan dicuci menggunakan air bersih. Lalu dikeringkan dengan menggunakan sinar matahari selama 5 hari. Kemudian Eceng gondok dikeringkan kembali dalam oven pada suhu $60^{\circ} \mathrm{C}$ selama 24 jam dan didiamkan pada suhu kamar. Eceng gondok kering kemudian dibakar (karbonisasi) menggunakan tanur pada suhu $300^{\circ} \mathrm{C}$ dengan kadar oksigen rendah sampai menjadi arang dan didinginkan hingga mencapai suhu kamar. Arang yang telah terbentuk dihaluskan dengan lumpang dan alu, lalu dibersihkan kembali dengan menggunakan aquades. Kemudian arang dikeringkan dalam oven pada suhu $105^{\circ} \mathrm{C}$ selama 1 jam lalu diayak menggunakan ayakan ukuran 70 mesh. Selanjutnya arang ditimbang menggunakan neraca digital dan di simpan ditempat yang kering dan tertutup.

\section{Pengaruh variasi berat adsorben terhadap adsorpsi Fenol}

$25 \mathrm{~mL}$ air limbah PLTU dimasukkan ke dalam erlenmeyer. Kemudian $10 \mathrm{mg}$ adsorben arang eceng gondok ditambahkan ke dalam larutan tersebut. Setelah itu Erlenmeyer ditutup menggunakan aluminium foil. Kemudian larutan dikocok menggunakan shaker selama waktu 1 jam. Selanjutnya larutan didiamkan selama 24 jam. Setelah itu larutan disaring menggunakan kertas saring whatman 41. Selanjutnya konsentrasi larutan diukur menggunakan spektro direct. Setelah itu melakukan perlakuan yang sama dengan variasi berat pada masing-masing $20 \mathrm{mg}, 30 \mathrm{mg}, 40$ $\mathrm{mg}$ dan $50 \mathrm{mg}$. Pengukuran diulangi sebanyak tiga kali.

\section{Analisis Sampel}

Menekan tombol zero pada alat spektro direct, selanjutnya sampel dimasukkan ke dalam chamber sebanyak $10 \mathrm{~mL}$, lalu tablet fenol 1 dan tablet fenol 2 ditambahkan ke dalam chamber dan dikocok hingga tablet fenol larut. Kemudian chamber dimasukkan ke dalam alat spektro direct hingga sejajar dengan tanda $\mathrm{X}$, selanjutnya tekan tombol test, kemudian tunggu untuk waktu reaksi selama 5 menit. Setelah reaksi berakhir pembacaan secara otomatis akan dimulai. Dan hasilnya akan dihitung $\mathrm{mg} / \mathrm{L}$ fenol.

\section{Hasil dan Pembahasan}

Penelitian ini dilakukan untuk melihat berat adsorben optimum dan kapasitas adsorpsi. Penentuan konsentrasi fenol dalam larutannya diukur menggunakan spektrofotometer spektrodirect dengan jumlah fenol terjerap (Cb) oleh arang eceng gondok adalah selisih konsentrasi fenol mula-mula $(\mathrm{Ci})$ dengan konsentrasifenol padasaatkesetimbangan(Ceq).

\section{Data Hasil Pembuatan Arang}

Arang yang diperoleh pada penelitian ini sebesar 6,56 gram, setelah pengayakan diperoleh sebesar 5,43 gram. Sampel yang digunakan memiliki kadar air sebesar $92,46 \%$ dan kadar abu sebesar $1,3 \%$ dari 100 gram sampel.

Tanaman eceng gondok yang sudah dipisahkan dari akarnya dibersihkan dengan air yang mengalir, kemudian dikeringkan menggunakan sinar matahari selama 5 hari. Setelah kering, eceng gondok tersebut di keringkan kembali menggunakan oven pada suhu $60^{\circ} \mathrm{C}$ selama $24 \mathrm{jam}$. Hal ini bertujuan untuk menghilangkan kadar air yang masih terdapat pada eceng gondok. Kemudian memasukkan eceng gondok ke dalam tanur pada suhu $300^{\circ} \mathrm{C}$ hingga menjadi arang. Hal ini untuk melakukan proses pirolisis dimana hasil dari proses tersebut akan menghasilkan karbon sebagai hasil akhirnya. Setelah itu, arang dihaluskan menggunakan lumpang dan alu dan dibersihkan menggunakan aquades untuk menghilangkan zat-zat pengotor yang masih tersisa didalam arang. Selanjutnya memasukkan arang ke dalam oven pada suhu $105^{\circ} \mathrm{C}$ selama 1 jam untuk proses pengeringan dan penghilangan kadar air yang masih terdapat di dalam arang dan ditimbang diperoleh berat arang sebesar 11,53 gram. Setelah melalui proses pengeringan arang diayak ukuran lolos 70 mesh, agar diperoleh ukuran partikel adsorben yang lebih halus dan memiliki luas permukaan yang lebih besar. Sesuai dengan pernyataan Oscik \& Cooper (1982) menyatakan bahwa, semakin besar luas permukaan adsorben semakin besar pula kapasitas suatu adsorben dalam mengadsorpsi suatu adsorbat. Pengayakan ini merupakan langkah terakhir pada proses pembuatan arang dimana berat bersih arang yang di dapatkan adalah 5,43 gram. (Oscik \& Cooper, 1982)

\section{Konsentrasi Fenol pada Limbah PLTU}

Data hasil pengukuran konsentrasi fenol pada air masuk kondensor adalah 1,15 $\mathrm{mg} / \mathrm{L}$ sedangkan konsentrasi fenol pada air keluar kondensor adalah 4,57 mg/L. 
Pengukuran Konsentrasi Fenol Yang teradsorpsi Pada Variasi Berat Adsorben

Data hasil pengukuran konsentrasi Fenol yang teradsorpsi pada variasi berat adsorben dapat dilihat pada Tabel 1

Tabel 1 Hasil Pengukuran Konsentrasi Fenol yang Teradsorpsi pada Variasi Berat Adsorben

\begin{tabular}{cccccc}
\hline No & $\begin{array}{c}\text { Berat Arang } \\
(\mathrm{mg} / \mathrm{L})\end{array}$ & $\mathrm{C}_{\mathrm{i}}(\mathrm{mg} / \mathrm{L})$ & $\begin{array}{c}\overline{\mathrm{Ceq}} \\
(\mathrm{mg} / \mathrm{L})\end{array}$ & $\begin{array}{c}\overline{\mathrm{Cb}} \\
(\mathrm{mg} / \mathrm{L})\end{array}$ & $\overline{\% \text { Fenol }}$ \\
1 & 10 & 4,57 & $0,79 \pm 0,02$ & $3,78 \pm 0,02$ & $82,78 \pm 0,34$ \\
2 & 20 & 4,57 & $0,50 \pm 0,02$ & $4,07 \pm 0,02$ & $89,13 \pm 0,34$ \\
3 & 30 & 4,57 & $0,66 \pm 0,02$ & $3,91 \pm 0,02$ & $85,49 \pm 0,34$ \\
4 & 40 & 4,57 & $0,93 \pm 0,03$ & $3,64 \pm 0,03$ & $79,72 \pm 0,55$ \\
5 & 50 & 4,57 & $1,17 \pm 0,02$ & $3,40 \pm 0,02$ & $74,42 \pm 0,44$ \\
\hline \multicolumn{5}{l}{ Keterangan : $C_{b}=\left(C_{i}-C_{e a}\right)$}
\end{tabular}

Variasi Berat Adsorben Terhadap Adsorpsi Fenol

Penentuan berat optimum adsorben pada penelitian ini dilakukan dengan menggunakan adsorben sebanyak 10-50 mg. Tujuan dari penentuan berat optimum adsorben adalah untuk mengetahui jumlah minimum adsorben yang dapat digunakan untuk proses adsorpsi, sehingga jumlah penggunaan adsorben lebih efisien dan lebih hemat biaya. Pada penelitian ini, konsentrasi fenol yang diperoleh pada analisis awal limbah PLTU sebelum perlakuan adalah $4,57 \mathrm{mg} / \mathrm{L}$. Dimana data penentuan berat optimum adsorben dapat dilihat pada Tabel 1 Berdasarkan data tersebut maka persentase adsorpsi pada berbagai berat adsorben dapat kita ilustrasikan seperti pada Gambar 1

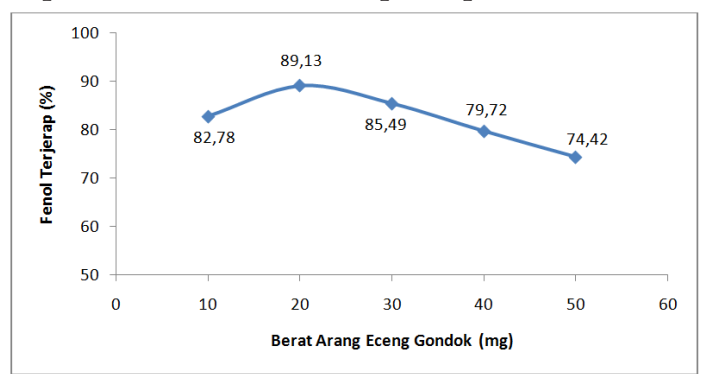

Gambar 1 Kurva Hubungan antara Berat Arang terhadap \% Fenol Terjerap

Berdasarkan Gambar 1, berat adsorben meningkat dari $10 \mathrm{mg}$ sampai $50 \mathrm{mg}$ sehingga menyebabkan naiknya persentase fenol yang terjerap, namum pada berat adsorben 30 hingga $50 \mathrm{mg}$ jerapannya relatif menurun. Peningkatan adsorpsi tersebut disebabkan karena bertambahnya jumlah arang yang berinteraksi dengan fenol yang berada didalam limbah PLTU selain itu pada berat adsorben $20 \mathrm{mg}$ penjerapan optimum terjadi dengan persen penjerapan $89,13 \%$ hal ini dikarenakan ketersediaan permukaan aktif pada adsorben sebanding dengan banyaknya adsorbat yang akan terjerap pada permukaan adsorben dalam larutan, dimana permukaan adsorben telah terisi penuh atau dipadati oleh adsorbat. Persen penjerapan tidak mencapai atau mendekati $100 \%$ karena seperti yang kita ketahui bahwa limbah PLTU tidak hanya mengandung senyawa fenol, sehingga yang ikut terjerap bukan hanya senyawa fenol saja melainkan senyawa kimia atau zat-zat kimia yang terkandung dalam limbah PLTU tersebut. Dari data diatas dapat dilihat bahwa penjerapan $30 \mathrm{mg}$ lebih besar dibandingkan penjerapan pada $10 \mathrm{mg}$ arang. Pada berat arang $10 \mathrm{mg}$ ruang kosong pada arang telah terisi oleh adsorbat (fenol) dan juga zat-zat dan senyawa kimia lainnya yang terdapat dalam limbah PLTU sedangkan pada larutan masih tersisa adsorbat (fenol) yang belum terjerap sehingga penjerapan belum optimum. Selanjutnya adsorpsi fenol semakin menurun pada berat arang 30-50 mg, hal ini dikarenakan semakin banyak arang yang ditambahkan semakin banyak ruang kosong atau luas permukaan yang tersedia pada adsorben. Banyaknya ruang yang kosong menyebabkan ikatan antar fenol yang terjerap tidak kuat sehingga fenol yang telah terjerap pada permukaan arang kembali terlepas, karena pada waktu pengocokkan arang melakukan kontak dengan fenol maka semakin besar pula kemungkinan sisi aktif dari arang untuk berikatan secara kovalen dengan fenol. Arang merupakan padatan berpori yang sebagian besar terdiri dari unsur karbon bebas dan masing-masing berikatan secara kovalen (Murdika, 2009). Selain itu, hal tersebut dapat disebabkan oleh kesesuaian dari ukuran molekul fenol dengan pori adsorben. Fenol dengan ukuran yang tidak sesuai dengan pori adsorben akan sering terlepas dari pori adsorben. Sehingga peningkatan berat arang relatif tidak lagi mempengaruhi peningkatkan penjerapan fenol oleh arang tersebut. Kapasitas adsorpsi karbon terhadap suatu zat terlarut dipengaruhi oleh karbon dan zat yang terlarut, kelarutan, struktur molekul, dan berat molekul zat terlarut. Kemampuan karbon untuk mengadsorpsi berbeda untuk masing-masing senyawa. Limbah PLTU tidak hanya mengandung fenol akan tetapi terdapat juga senyawasenyawa kimia didalam limbah tersebut. Limbah PLTU juga mengandung jumlah COD, BOD yang tinggi dimana menurut penelitian Valentina, dkk. (2013), bahwa arang eceng gondok yang teraktivasi asam phospat mampu menurunkan kekeruhan, COD dan BOD. Pada penelitian Uji Kemampuan Karbon 
Aktif dari Limbah Kayu dalam Sampah Kota untukPenyisihan Fenol, dalamvariasiberatarang aktiflimbah kayu di peroleh hasil sebagai berikut:

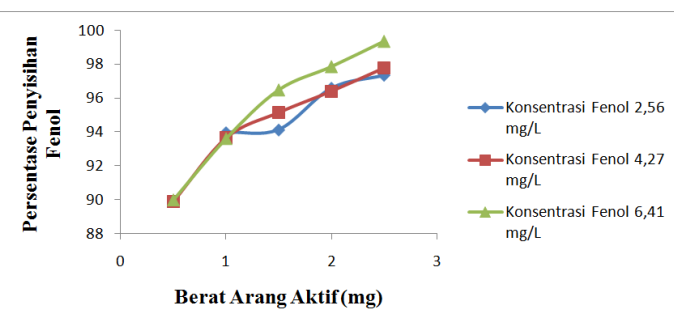

Gambar 2 Presentasi Penyisihan Fenol oleh Arang Aktif Kayu Merbau

Grafik pada gambar 2 dapat dilihat bahwa semakin bertambah jumlah arang aktif yang digunakan maka semakin besar pula penjerapan yang dilakukan oleh arang aktif dari limbah kayu sehingga pada penelitian tersebut berat optimum penjerapan fenol oleh arang aktif limbah kayu belum didapatkan, sedangkan pada penelitian yang dilakukan menggunakan arang hayati eceng gondok pada variasi berat 20 $\mathrm{mg}$ telah terjadi penjerapan optimum. Proses aktivasi pada arang limbah kayu berfungsi untuk meningkatkan luas permukaan melalui pembukaan pori-pori sehingga daya adsorpsi dapat ditingkatkan. Hal tersebut sesuai dengan penelitian Valentina, dkk. (2013) yang mengatakan bahwa arang aktif memiliki pori pori yang lebih besar dibandingkan dengan arang biasa, sehingga menyebabkan proses penjerapannya lebih besar. Perbandingan arang eceng gondok dengan arang aktif limbah kayu dapat dilihat bahwa persentasi penjerapan lebih besar dilakukan oleh arang aktif limbah kayu.

Pada penelitian ini, pH limbah PLTU (air keluar kondensor) tidak diukur. Sebagaimana kita ketahui, bahwa $\mathrm{pH}$ sampel yang akan dijerap sangat berpengaruh dalam proses adsorpsi. Hal ini dikarenakan $\mathrm{pH}$ limbah PLTU semakin bertambah seiring berjalannya waktu. Pada bulan Juni tahun 2015 kadar fenol pada limbah PLTU (air keluar kondensor) adalah sebesar 1,9 mg/L (Akbar, 2015), sedangkan pada bulan desember 2015 peneliti memperoleh kadar fenol pada limbah PLTU adalah sebesar $4,57 \mathrm{mg} / \mathrm{L}$, seperti yang kita ketahui bahwa fenol bersifat asam. Fenol 10000 kali lebih asam dibandingkan air. Oleh karena itu, penelitian ini hanya melihat kemampuan jerapan arang eceng gondok dengan variasi berat arang saja, tanpa melihat faktor-faktor lain yang mempengaruhi proses adsorpsi, karena metode ini diharapkan dapat diterapkan di PLTU Palu sehingga kadar fenol yang dihasilkan pada limbah PLTU dapat berkurang.

\section{Kesimpulan}

Berat optimum yang diperlukan arang eceng gondok untuk menjerap fenol pada limbah PLTU (air keluar kondensor) adalah sebesar $20 \mathrm{mg}$, berat fenol yang terjerap yaitu 4,07 $\mathrm{mg} / \mathrm{L}$, dan persentase fenol yang terjerap yaitu $89,13 \%$, dengan kapasitas jerapan maksimum arang eceng gondok dalam menjerap fenol pada limbah PLTU (air keluar kondensor) sebesar $3,03 \mathrm{mg} \mathrm{fenol} / \mathrm{g}$ arang eceng gondok.

\section{Ucapan Terima Kasih}

Penulis mengucapkan terima kasih kepada kepala laboran laboratorium kimia FKIP Untad dan semua pihak yang telah membantu dalam pelaksanaan penelitian ini.

\section{Referensi}

Akbar. (2015). Analisis kadar fenol air laut dan udara di lingkungan sekitar PLTU kelurahan Panau kecamatan Tawaeli Palu Utara. Program Studi Pendidikan Kimia Jurusan Pendidikan MIPA Fakultas Keguruan dan Ilmu Pendidikan Universitas Tadulako. Skripsi: tidak diterbitkan.

Dewilda, Y., Afrianita, R., \& Iman, F. F. (2012). Degradasi senyawa fenol oleh mikroorganisme laut. Jurnal Teknik Lingkungan, 9(1), 59-73.

Faisal, M. (2015). Efisiensi penyerapan logam $\mathrm{Pb}^{2+}$ dengan menggunakan campuran bentonit dan enceng gondok. Jurnal Teknik Kimia, 4(1), 20-24.

Gerrard, A. M., Junior, J. P., Páca, A. K. J., Stiborová, M., \& Soccol, C. R. (2006). Simple models for the continuous aerobic biodegradation of phenol in a packed bed reactor. International Journal Brazilian Archives of Biology and Technology, 49(4), 669-676.

Hamamah, F., \& Trihadiningrum, Y. (2008). Penyisihan fenol pada limbah industri dari PT XYZ dengan eceng gondok (eichhornia crassipes). Prosiding Seminar Nasional Manajemen Teknologi VII.

Juliandini, F., \& Trihadiningrum, Y. (2008). Uji kemampuan karbon aktif dari limbah kayu dalam sampah kota untuk penyisihan fenol. 
Prosiding Seminar Nasional Manajemen Teknologi VII Program Studi MMT-ITS.

Krystyanti, K. (2008). Adsorpsi merkuri (II) oleh biomassa enceng gondok (eichornia crassipes) yang diimmobilisasi pada matriks polisilikat menggunakan metode kolom. Jurusan Kimia Fakultas Sains dan Teknologi Universitas Islam Negeri Malang. Skripsi: tidak diterbitkan.

Murdika, A. (2009). Aplikasi teknik kombinasi adsorpsi dan elektrolisis untuk menurunkan kandungan fenol dalam limbah industri bahan kimia sanitasi. Jurusan Kimia Fakultas Matematika dan Ilmu Pengetahuan Alam Universitas Indonesia. Skripsi: tidak diterbitkan.

Oscik, J., \& Cooper, L. (1982). Adsorptionz. John Wiley and Sons: New York.

Pambayun, G. S., Yulianto, R. Y. E., Rachimoellah, M., \& Putri, E. M. M. (2013). Pembuatan karbon aktif dari arang tempurung kelapa dengan aktivator $\mathrm{ZnCl} 2$ dan $\mathrm{Na} 2 \mathrm{CO} 3$ sebagai adsorben untuk mengurangi kadar fenol dalam air limbah. Jurnal Teknik POMIST, 2(1), 116-120.

Podolar, K., Mandal, L., \& Banerjee, G. C. (1991). Studies on water hyacinth (eichornia crossipes) chemical composition of the plant and water from different habitats. Indian Veterinary Journal, 68, 883-837.

Reri, A., Yommi, D., \& Rafiola, F. (2012). Studi penentuan kondisi optimum fly ash sebagai adsorben dalam menyisihkan logam berat timbal (Pb). Jurnal Teknik Lingkungan
Universitas Andalas, 9(1), 37-43.

Shofiyani, A., \& Gusrizal. (2006). Determination of $\mathrm{pH}$ effect and capacity of heavy metals adsorption by water hyacinth (eichhornia crassipes) biomass. Indonesia Journal of Chemistry, 6(1), 56-60.

Slamet, Bismo, S., Arbianti, R., \& Sari, Z. (2006). Penyisihan fenol dengan kombinasi proses adsorpsi dan fotokatalis menggunakan karbon aktif dan TiO2. Jurnal Teknologi, 4, 303-311.

Valentina, A. E., Miswadi, S. S., \& Latifah. (2013). Pemanfaatan arang eceng gondok dalam menurunkan kekeruhan, COD, BOD pada air sumur. Indonesian Journal of Chemical Science, 2(2), 84-89.

Wirawan, T. (2012). Adsorpsi fenol oleh arang aktif dari tempurung biji jarak pagar (jatropha curcas 1.). Mulawarman Scientific, 11(1), 19-28.

Yousef, R. I., El-Eswed, B., \& Al-Muhtaseb, A. (2011). Adsorption characteristics of natural zeolite as solid adsorbents for phenol removal from aqueous solutions: kinetics, mechanism, and thermodynamics studies. Chemical Engineering Journal, 171, 11431149.

Zaman, B., \& Sutrisno, E. (2006). Kemampuan penyerapan eceng gondok terhadap amoniak dalam limbah rumah sakit berdasarkan umur dan lama kontak (Studi kasus: RS Panti Wilasa, Semarang). Jurnal Presipitasi, 1(1), 49-54. 